\title{
Inconsistent response of soil bacterial and fungal communities in aggregates to litter decomposition during short-term incubation
}

\author{
Jingjing Li ${ }^{1,2}$, Chao Yang ${ }^{\text {Corresp. } 1}$ \\ ${ }^{1}$ College of Grassland Science, Qingdao Agricultural University, Qingdao, China \\ College of Grassland Science and Technology, China Agricultural University, Beijing, China \\ Corresponding Author: Chao Yang \\ Email address: yc697525@163.com
}

Background. Soil aggregate-size classes and microbial communities within the aggregates are important factors regulating the soil organic carbon (SOC) turnover. However, the response of soil bacterial and fungal communities in aggregates to litter decomposition in different aggregate-size classes is poorly understand.

Methods. Soil samples from un-grazed natural grassland were separated into four dry aggregate classes of different sizes (2-4 mm, 1-2 mm, 0.25-1 mm and $<0.25 \mathrm{~mm}$ ). Two types of plant litter (leaf and stem) of Leymus chinensis were added to each of the four aggregate class samples. The CO2 release rate, SOC storage and soil microbial communities were measured at the end of the 56-day incubation.

Results. The results showed that the 1-2 $\mathrm{mm}$ aggregate had the highest bacterial Shannon and $\mathrm{CO} 2$ release in CK and leaf addition treatments, and the SOC in the $<0.25 \mathrm{~mm}$ aggregate was higher than that in the others across the treatments. The relative abundance of Ascomycota was higher in the 2-4 $\mathrm{mm}$ and $<0.25 \mathrm{~mm}$ aggregates than in the $1-2 \mathrm{~mm}$ and $0.25-1 \mathrm{~mm}$ aggregates in the treatment without litter addition, and the relative abundance of Aphelidiomycota was lower in the $2-4 \mathrm{~mm}$ and $<0.25 \mathrm{~mm}$ aggregates than in the 1-2 $\mathrm{mm}$ and $0.25-1 \mathrm{~mm}$ aggregates. Also, litter addition increased the relative abundance of Proteobacteria and Bacteroidetes, but decreased the relative abundance of Acidobacteria, Gemmatimonadetes, and Actinobacteria. The relative abundance of Ascomycota and Aphelidiomycota increased by more than $10 \%$ following leaf litter addition. The bacterial Shannon index had a significantly positive and direct effect on SOC concentration and CO2 release, while the fungal Shannon index was significantly correlated with SOC concentration. Our results indicate that the soil bacterial diversity contributes positively to both carbon emissions and carbon storage, whereas soil fungal diversity can promote carbon storage and decrease carbon emissions. 
1 Inconsistent response of soil bacterial and fungal

2 communities in aggregates to litter decomposition

\section{3 during short-term incubation}

4 Jingjing $\mathrm{Li}^{1,2}$, Chao Yang ${ }^{1 *}$

$5 \quad{ }^{1}$ College of Grassland Science, Qingdao Agricultural University, Qingdao, China

$6 \quad{ }^{2}$ College of Grassland Science and Technology, China Agricultural University, Beijing, China

$7 \quad$ *Correspondence author:

8 Email: yc697525@163.com (Chao Yang). 


\section{Abstract:}

10 Background. Soil aggregate-size classes and microbial communities within the aggregates are important 11 factors regulating the soil organic carbon (SOC) turnover. However, the response of soil bacterial and fungal 12 communities in aggregates to litter decomposition in different aggregate-size classes is poorly understand.

13 Methods. Soil samples from un-grazed natural grassland were separated into four dry aggregate classes of different sizes (2-4 mm, 1-2 mm, $0.25-1 \mathrm{~mm}$ and $<0.25 \mathrm{~mm}$ ). Two types of plant litter (leaf and stem) of Leymus chinensis were added to each of the four aggregate class samples. The $\mathrm{CO}_{2}$ release rate, $\mathrm{SOC}$ storage and soil microbial communities were measured at the end of the 56-day incubation.

Results. The results showed that the 1-2 mm aggregate had the highest bacterial Shannon and $\mathrm{CO}_{2}$ release in control and leaf addition treatments, and the $\mathrm{SOC}$ in the $<0.25 \mathrm{~mm}$ aggregate was higher than that in the others across the treatments. The relative abundance of Ascomycota was higher in the $2-4 \mathrm{~mm}$ and $<0.25 \mathrm{~mm}$ aggregates than in the 1-2 mm and $0.25-1 \mathrm{~mm}$ aggregates in the treatment without litter addition, and the relative abundance of Aphelidiomycota was lower in the 2-4 $\mathrm{mm}$ and $<0.25 \mathrm{~mm}$ aggregates than in the $1-2 \mathrm{~mm}$ and 0.25-1 mm aggregates. Also, litter addition increased the relative abundance of Proteobacteria and Bacteroidetes, but decreased the relative abundance of Acidobacteria, Gemmatimonadetes, and Actinobacteria. The relative abundance of Ascomycota and Aphelidiomycota increased by more than $10 \%$ following leaf litter addition. The bacterial Shannon index had a significantly positive and direct effect on SOC concentration and $\mathrm{CO}_{2}$ release, while the fungal Shannon index was significantly correlated with SOC concentration. Our results indicate that the soil bacterial diversity contributes positively to both carbon emissions and carbon storage, whereas soil fungal diversity can promote carbon storage and decrease carbon emissions. 


\section{Introduction}

Litter decomposition is a key step in the carbon cycle (Bonan et al. 2013; Schmidt et al. 2011; Wieder et al. 2013), especially in grassland ecosystems, which cover $40 \%$ of the earth's land surface (Lu et al. 2017), and possess about $20 \%$ of the soil organic carbon (SOC) stocks globally (Schuman et al. 2002). The majority of studies have shown that litter decomposition usually depends on three main drivers: climate factors (soil moisture and temperature) (He et al. 2010; Riggs et al. 2015; Wang et al. 2016; Zhong et al. 2017), litter quality (i.e., its chemical composition) (Hishinuma et al. 2017; Zhang et al. 2016), and decomposer activity (Jia et al. 2016; Keiser \& Bradford 2017). In addition, there is increasing evidence that soil microbial communities influence litter decomposition rates over and above climate and litter quality controls (Bradford et al. 2016; Schimel \& Schaeffer 2012). Studies on litter decomposition have focused on the bacterial community composition and have confirmed the involvement of a series of colonizers in the litter decomposition process (Fanin \& Bertrand 2016). Soil fungi are also one of the major microbial decomposers of plant litter, being able to decompose the recalcitrant component (Liang et al. 2017).

Soil aggregates are the basic units of soil structure (Bronick \& Lal 2005) and are generally sub-divided into macro-aggregates $(>0.25 \mathrm{~mm})$ and micro-aggregates $(<0.25 \mathrm{~mm})$ (Yang et al. 2017). Soil microbial community compositions are non-uniformly distributed in the soil aggregates and may be sensitive to changes in soil environments (Six et al. 2004). In general, the distribution of bacteria in soil varies with aggregate size (Neumann et al. 2013), and the microbial biomass associated with soil aggregates has been reported to be heterogeneously distributed (Wang et al. 2017). Only a few studies have used sequencing analysis to assess the bacterial communities of aggregates (Gupta \& Germida 2015). Although our previous study found the distribution of soil bacteria and fungi in aggregates to be inverse (Yang et al. 2019a), very little is known regarding their contribution to litter decomposition in different aggregate fractions. In addition, soil microbial processes are regulated by constraints in soil $\mathrm{pH}$, which is considered to be an important factor controlling the balance of fungal to bacterial growth in the soil (Lauber et al. 2009; Rousk et al. 2010).

We designed a two-factor incubation experiment in the laboratory: one was litter quality (leaf and stem), while the other was soil aggregate size. The SOC mineralization, SOC content, soil $\mathrm{pH}$, and soil microbial community were measured at the end of the incubation period. We hypothesized that (1) the soil bacterial and 
56 fungal communities are unevenly distributed in the aggregate fractions, (2) different aggregate sizes respond 57 differently to the quality of the litter addition, and (3) the correlation between soil properties and soil microbial 58 diversities controls litter decomposition.

59 Materials and methods

60

\section{Material collection and preparation}

The soil samples were collected from one type of ungrazed natural grassland located in Guyuan, Hebei Province, China $\left(41^{\circ} 46^{\prime} \mathrm{N}, 115^{\circ} 41^{\prime} \mathrm{E}\right.$, elevation $\left.1380 \mathrm{~m}\right)$ in May of 2018, the initial stage of growing season. This area is a typical temperate zone characterized by a mean annual precipitation of $430 \mathrm{~mm}$ and a mean annual temperature of $1.4{ }^{\circ} \mathrm{C}$. The minimum monthly mean air temperature is $-18.6{ }^{\circ} \mathrm{C}$ in January and the site reaches a maximum of $21.1^{\circ} \mathrm{C}$ in July. The site has a calcic-orthic Aridisol soil with a loamy-sand texture.

In brief, the top layer $(0-15 \mathrm{~cm})$ of the soil $(\sim 200 \mathrm{~kg})$ at one location was collected in plastic bags with a shovel, and was quickly transported to the laboratory by car, upon which the plant roots and leaves were carefully removed by hand and the soil was air-dried. The soil was sieved to separate large macro-aggregates ( $2-4 \mathrm{~mm})$, macro-aggregates $(1-2 \mathrm{~mm})$, meso-aggregates $(0.25-1 \mathrm{~mm})$ and micro-aggregates $(<0.25 \mathrm{~mm})$ according to Yang et al. (2017). In brief, the undisturbed soil was shaken through four sieves (4, 2, 1 and, $0.25 \mathrm{~mm})$ for 2 $\mathrm{min}$, and the large macro-aggregates $(2-4 \mathrm{~mm})$ were collected from the $2 \mathrm{~mm}$ sieve, macro-aggregates $(1-2 \mathrm{~mm})$ from the $1 \mathrm{~mm}$ sieve, and meso-aggregates $(0.25-1 \mathrm{~mm})$ from the $0.25 \mathrm{~mm}$ sieve, and the micro-aggregates $(<0.25 \mathrm{~mm})$ were passed through the $0.25 \mathrm{~mm}$ sieve. Soil aggregates were stored hermetically at room temperature after until collecting the litter samples.

In September 2018, two types of plant litter (leaf and stem) were obtained from the dominant species (Leymus chinensis) in the same location from where the soil samples were collected. The litter was brought to the laboratory, and dried at $65^{\circ} \mathrm{C}$ to constant weight. In order to avoid the effects of litter size on decomposition, the plant litter was cut into ca. 1-cm-long sections for the incubation experiment. Some basic characteristics for the soils in Table 1 were cited from our previous studies (Yang et al. 2017; Yang et al. 2019b).

\section{Experimental design and incubation study}

The three replicates of air-dried soil samples (200 g dry weight) of each aggregate size class $(2-4,1-2$, 
82

$0.25-1$, and $<0.25 \mathrm{~mm}$ ) were placed at the bottom of $1000 \mathrm{~mL}$ jars. The jars were new and unused, and we did not sterilize them beforehand because our incubator has the function of ultraviolet sterilization. The two plant litter types ( $3 \mathrm{~g}$ of dry matter) were combined with $200 \mathrm{~g}$ of dry soil in the microcosms. Although air drying of soil sample is not representative of the communities that originally existed in the soil, it can represent the difference in the distribution of microbes in our incubation conditions (Yang et al. 2019a). No litter addition was used as the control check (CK). There were a total of 72 microcosms ( 4 aggregate size $\times 3$ litter types $\times 3$ replications $\times 2$ sampling times). The moisture content was adjusted to $30 \%$ by weighing each microcosm and adding distilled water, and 30\% is the maximum field water capacity of the soil (Yang et al. 2019a). Each jar was covered with perforated cling film to reduce humidity loss while allowing gaseous exchange. The jars were pre-incubated for 3 days at a constant temperature of $25^{\circ} \mathrm{C}$. After the pre incubation period, the jars were maintained for 56 days at $25{ }^{\circ} \mathrm{C}$. During the 56-day incubation, the soil moisture of each microcosm was maintained consistently by weighing each microcosm every week and adding distilled water. After 28 and 56 days of incubation, 36 microcosms were retrieved, respectively. Litter was removed from each microcosm, cleaned with water to remove adhering soil particles, dried $\left(65^{\circ} \mathrm{C}, 48 \mathrm{~h}\right)$ and weighed.

\section{Soil aggregate respiration measurements}

Soil aggregate respiration was measured at the end of the incubation. In brief, small vials with $5 \mathrm{~mL}$ of 1 $\mathrm{M} \mathrm{NaOH}$ were placed in the incubation jars to trap $\mathrm{CO}_{2}$ for $24 \mathrm{~h}$. The soil respiration $\left(\mathrm{g} \mathrm{CO}_{2}-\mathrm{C} \mathrm{g}^{-1}\right.$ soil day-1) was estimated by titrating $2 \mathrm{~mL} \mathrm{NaOH}$ from each trap with $0.1 \mathrm{M} \mathrm{HCl}$ after adding $2 \mathrm{~mL} 1 \mathrm{M} \mathrm{BaCl}_{2}(1: 1)$ and a phenolphthalein indicator using a Digital Burette continuous E (VITLAB, Germany) according to Yang et al. (2018). At the end of the soil respiration incubation, $10 \mathrm{~g}$ of soil sample was collected immediately after the removal of the plant litter and stored at $-80^{\circ} \mathrm{C}$ for microbiological sequencing. The remaining soil samples were air-dried for SOC and $\mathrm{pH}$ assays. SOC concentration was measured using an elemental analyzer (TOC, Elementar, Germany), and soil total nitrogen (TN) was measured using the FOSS Kjeltec 2300 Analyser Unit (FOSS, Hillerød, Sweden). Soil $\mathrm{pH}$ was determined after shaking a soil water (1: $2.5 \mathrm{wt} / \mathrm{vol})$ suspension for 30 $\min$.

\section{Soil DNA extraction and sequencing}

Genomic DNA was extracted from each soil aggregate sample using an E.Z.N.A. ${ }^{\circledR}$ stool DNA Kit (Omega 
109

110

111

112

113

114

115

116

117

118

119

120

121

122

123

124

125

126

127

128

129

130

131

132

133

134

Bio-tek, Norcross, GA, USA) according to the manufacturer's instructions. All extracted DNA samples were stored at $-20^{\circ} \mathrm{C}$ before further analysis. The V3-V4 regions of the bacterial $16 \mathrm{~S}$ rRNA gene were amplified using universal primers 338F (5'-ACTCCTACGGGAGGCAGCAG-3') and 806R (5'GGACTACHVGGGTWTCTAAT-3') (Lane et al. 1985), and the fungal ITS gene was amplified by the ITS1 (5'-CTTGGTCATTTAGAGGAAGTAA-3') and ITS2 (5'-GCTGCGTTCTTCATCGATGC-3') primers (White et al. 1990). The PCR program was as follows: 5 min initial denaturation at $95^{\circ} \mathrm{C} ; 25$ cycles of denaturation at $95^{\circ} \mathrm{C}(30 \mathrm{~s})$, annealing at $56^{\circ} \mathrm{C}(30 \mathrm{~s})$, elongation at $72^{\circ} \mathrm{C}(40 \mathrm{~s})$; and a final extension at $72^{\circ} \mathrm{C}$ for $10 \mathrm{~min}$. PCR reactions were performed in triplicate $25 \mu \mathrm{L}$ mixtures containing $2.5 \mu \mathrm{L}$ of $10 \times$ Pyrobest Buffer, $2 \mu \mathrm{L}$ of 2.5 Mm dNTPs, $1 \mu \mathrm{L}$ of each primer (10 Mm), $0.4 \mathrm{U}$ of Pyrobest DNA Polymerase (TaKaRa), and $15 \mathrm{ng}$ of template DNA. The amplicon mixture sequenced on an Illumina HiSeq 2500 platform (Biomaker, Beijing).

\section{Processing of sequencing data}

The extraction of high-quality sequences was first conducted with the QIIME package (Quantitative Insights Into Microbial Ecology) (v1.2.1). The original sequence data were sorted into valid reads after demultiplexing and quality-filtering with the following rules: (i) 300-bp reads were truncated at any site receiving an average quality score of $<20$ over a 50-bp sliding window, and truncated reads shorter than $50 \mathrm{bp}$ were discarded; (ii) exact barcode matching, less than two nucleotide mismatches in the primer, and no ambiguous characters in the read; (iii) only overlapping sequences longer than $10 \mathrm{bp}$ were assembled according to their overlapped sequence (Chen et al. 2018). The unique sequence set was classified into operational taxonomic units (OTUs) under the threshold of 97\% identity using UCLUST.

\section{Statistical analysis}

The Shannon index was calculated as follows (Begon et al. 1986):

$$
\text { Shannon }=-\sum\left(\frac{\mathrm{Ni}}{\mathrm{N}}\right) \ln \left(\frac{\mathrm{Ni}}{\mathrm{N}}\right) \text {; }
$$

where $N$ is the total OTUs of the sample, $N i$ is the number of individuals in group $i$.

The SOC, TN, and $\mathrm{C} / \mathrm{N}$ ratios for the soil aggregates and plant litter were analyzed using a one-way analysis of variance (ANOVA) with a least significant difference (LSD) test at a significance level of $P<0.05$ using SPSS, version 19.0. Two-way ANOVA was used to test the effects of soil aggregate size and litter type on 
135 bacterial Shannon, fungal Shannon, $\mathrm{SOC}, \mathrm{CO}_{2}$ release, soil $\mathrm{pH}$ and litter mass loss. The structural changes in the

136 soil bacterial and fungal phyla were tested by nonmetric multidimensional scaling (NMDS) based on Bray-Curtis

137 similarity matrices using CANOCO, version 5.0. The relationship between environmental variables (pH and 138 SOC) and bacterial/fungal communities were tested by redundancy analysis (RDA) using CANOCO. For RDA

139

140

141

142

143

144

145

146

147 analysis, the significance of the effect of each variable, based on its eigenvalue, was tested using the Monte Carlo Permutation test, and the resulting significance level was determined by the $\mathrm{F}$ ratio and $P$-value. Hypothetical relationships among $\mathrm{SOC}$, soil $\mathrm{pH}$, bacterial diversity, fungal diversity, and soil respiration were quantified by structural equation modeling (SEM) using AMOS, version 21.0, and we used the non-significant chi-square $\left(\chi^{2}\right)$ test (the model has a good fit when $0 \leq \chi \chi^{2} \leq 2$ and $0.05<P \leq 1.00$ ) and the root mean square error of approximation (RMSEA, the model has a good fit when $0 \leq \mathrm{RMSEA} \leq 0.05$ and $0.10<P \leq 1.00$ ) to test the goodness of the model according to Yang et al. (2019a).

\section{Results}

\section{Microbial diversities and properties of the soil aggregates}

The microbial diversities and properties of the soil are listed in Table 2. According to the two-way ANOVA, the 1-2 $\mathrm{mm}$ aggregate had the highest bacterial Shannon and $\mathrm{CO}_{2}$ release in $\mathrm{CK}$ and leaf addition treatments, and the SOC in the $<0.25 \mathrm{~mm}$ aggregate was higher than that in the others across the treatments. Soil pH in the 0.25-1 mm aggregate was higher than that in the others across the treatments. In two litter addition treatments, the litter mass loss in the 1-2 $\mathrm{mm}$ and 2-4 mm aggregate was significantly higher than that in $0.25-1 \mathrm{~mm}$ and $<$ $0.25 \mathrm{~mm}$ soil aggregate on both day 28 and day 56.

\section{Response of soil bacteria and fungi to litter addition}

The soil bacterial and fungal community structures of the four aggregates were distinct from each other in the NMDS plots in the three litter-addition treatments (Fig. 1). The relative abundances of the dominant bacterial and fungal phyla in the soil aggregates are presented in Fig. 2. Proteobacteria and Acidobacteria were the main microflora in the soil aggregates in all three treatments, accounting for about $60 \%$ of the total abundance (Fig.

2A-C). The relative abundance of Ascomycota was higher in the $2-4 \mathrm{~mm}$ and $<0.25 \mathrm{~mm}$ aggregates than in the 1-2 $\mathrm{mm}$ and $0.25-1 \mathrm{~mm}$ aggregates in the treatment without leaf and stem addition, and the relative abundance 
161

162

163

164

165

166

167

168

169

170

171

172

173

174

175

176

177

178

179

180

181

182

183

184

185

186

187

of Aphelidiomycota was lower in the $2-4 \mathrm{~mm}$ and $<0.25 \mathrm{~mm}$ aggregates than in the $1-2 \mathrm{~mm}$ and $0.25-1 \mathrm{~mm}$ aggregates (Fig. 2D). However, leaf and stem addition increased the relative abundance of Ascomycota and Aphelidiomycota dramatically (Fig. 2E, F). The response of soil bacteria to leaf and stem addition was weak, changing less than $10 \%$ compare with the treatment lacking litter addition. Leaf and stem addition increased the relative abundance of Proteobacteria and Bacteroidetes, but decreased the relative abundance of Acidobacteria, Gemmatimonadetes, and Actinobacteria (Fig. 3A, B). However, the changes in soil fungi in response to leaf and stem addition were approximately $40 \%$ compared with no litter addition treatment, and the relative abundance of Ascomycota and Aphelidiomycota increased more than 10\% following the addition of leaf litter (Fig. 3C, D).

\section{The relationship between soil properties and microbial diversities}

RDA biplots were used to assess the physicochemical properties that influenced the abundance of the bacterial and fungal families. Overall, the combination of variables explained $65.9 \%$ and $31.5 \%$ of the bacterial (Fig. 4A) and fungal (Fig. 4B) community structure variances, respectively. Significant correlation was found between soil $\mathrm{pH}$ and soil bacterial communities $(\mathrm{F}=7.51, P=0.008)$, and SOC was also significantly correlated with the bacterial communities $(\mathrm{F}=5.91, P=0.028)$. In addition, the fungal communities were significantly correlated with the soil $\mathrm{pH}(\mathrm{F}=4.42, P=0.042)$ but not by SOC $(\mathrm{F}=2.41, P=0.091)$.

The SEM showed a good fit between soil $\mathrm{pH}$, microbial diversity, SOC, and respiration (Fig. $5 ; \chi^{2}=0.07$, $P=0.79 ;$ RMSEA $=0.00, P=0.80$ ). The fitted models explained $65 \%$ and $59 \%$ of the variance in SOC concentrations and $\mathrm{CO}_{2}$ release, respectively (Fig. 5A). Although an interaction was detected, there was no significant correlation between soil bacterial and fungal diversity with a correlation coefficient $\left(\mathrm{R}^{2}\right)$ of 0.14 . The SEM showed a significant interrelationship between fungal diversity and soil $\mathrm{pH}\left(\mathrm{R}^{2}=0.61, P<0.001\right)$. The bacterial Shannon index indicated a significantly positive and direct effect on SOC concentrations and $\mathrm{CO}_{2}$ release $(P<0.05)$, while the fungal Shannon index showed significantly correlated with SOC concentrations $(P$ $<0.001$ ). In addition, soil $\mathrm{pH}$ was significantly negatively correlated with $\mathrm{SOC}$ concentrations and $\mathrm{CO}_{2}$ release $(P<0.001)$. The standardized total effects derived from the SEM revealed that SOC concentrations were mainly driven by soil $\mathrm{pH}$, followed by the fungal and bacterial Shannon index, while $\mathrm{CO}_{2}$ release was mainly driven by soil $\mathrm{pH}$, followed by the bacterial and fungal Shannon index (Fig. 5B)

\section{Discussion}




\section{Bacterial and fungal diversity in soil aggregates}

Soil microbial diversity can better explain respiration than soil microbial biomass (Yang et al. 2019a). Furthermore, as macro-aggregates are generally dominated by soil fungi (Frey 2005), our study considered the diversity of both the soil bacteria and soil fungi. The $1-2 \mathrm{~mm}$ aggregate possessed both the highest bacterial Shannon and the lowest fungal Shannon under no litter addition, implying that soil bacteria and fungi in the same resources and spaces undergo interspecies interactions at the surface of the macro-aggregates (Effmert et al. 2012), and in this aggregate, bacterial diversity is favored. Litter addition eventually resulted in increased respiration; however, the Shannon index of both the bacteria and fungi decreased in the litter-addition treatment compared with no litter addition. Bamminger et al. (2014) suggested that litter addition increases microbial biomass and results in a shift in the composition of the soil microbial community, especially for soil fungi, which is consistent with the present study. The relative abundance of individual species will increase dramatically with the addition of litter, particularly that of soil fungi, resulting in a decline in microbial diversity.

\section{Response of soil bacteria and fungi to litter addition in soil aggregates}

Adding leaf litter to the soil has a positive effect on the soil microbial community as a result of the increased carbon and nutrient resources (Fanin \& Bertrand 2016). Bacterial communities are characterized by a series of colonizers during litter decomposition, with Proteobacteria, Actinobacteria and Bacteroidetes being the most abundant taxa found over the entire decomposition process (Purahong et al. 2016; Tlaskal et al. 2016). Our study demonstrates that Proteobacteria, Actinobacteria, Gemmatimonadetes and Bacteroidetes are the four mostimportant bacterial phyla within different aggregate sizes and litter addition treatments. In addition, Sun et al. (2017) found that bacterial abundance did not show a significant change following the addition of leaf litter, which corroborates the observations made in the present study. Liang et al. (2017) suggest that the addition of residues alters the soil microbial community composition and promotes fungal growth more than bacterial growth, which is in agreement with other studies that found that soil microorganisms respond to altered residue modifications by changing their community composition (Phillips et al. 2002) and also supports the observation that saprophytic fungi play a major role in the decomposition of residues (Meidute et al. 2008). Indeed, the fungal relative abundances in our study changed significantly following leaf litter addition, particularly Ascomycota and Aphelidiomycota. Given that Aphelidiomycota are not typical soil fungi, but widely present in soil when 
215 litter was added, its role in litter decomposition requires further study.

\section{Interactions between soil pH, SOC and microbial diversity after litter addition}

217 There is increasing evidence that soil microbial communities influence litter decomposition rates over and 218 above the climate and litter quality controls (Bradford et al. 2016; Schimel \& Schaeffer 2012). Adding leaf litter 219 to the soil increases the SOC and soil pH (Sun et al. 2017), and the soil pH tends to be neutral after adding litter

to acid soil. Similarity, in the present study, the soil $\mathrm{pH}$ decreased and tended to neutralize following litter addition, implying that litter addition regulates the acid-base balance of the soil. In addition, Rousk et al. (2010) suggested that soil $\mathrm{pH}$ has a strong influence on the diversity and composition of soil bacterial and fungal communities across a gradient. In contrast, soil microbial diversity also influences soil $\mathrm{pH}$. In the present study, soil fungal diversity decreased after litter addition, which decreased the soil $\mathrm{pH}$. The composition and diversity of the soil fungal and bacterial communities are thus often strongly correlated with soil pH (Lauber et al. 2009). In addition, the SEM showed a significant interrelationship between fungal diversity and soil $\mathrm{pH}$, and fungal diversity showed significant correlations with SOC concentrations, especially in the microenvironment of litter addition. The standardized total effects derived from the SEM revealed that SOC concentrations were mainly driven by soil $\mathrm{pH}$, followed by the fungal and bacterial diversity, while $\mathrm{CO}_{2}$ release was mainly driven by soil $\mathrm{pH}$, followed by the bacterial and fungal diversity. Such datasets are valuable in advancing our understanding of the role of different groups of microorganisms in soil and how microbial activities in the soil in response to litter addition contributes to nutrient fluxes in specific soil environments.

\section{Conclusions}

Our study shows a highly different response of bacteria and fungi in soil aggregates to litter addition. Litter addition increased the relative abundance of Proteobacteria and Bacteroidetes, but decreased the relative abundance of Acidobacteria, Gemmatimonadetes, and Actinobacteria. The relative abundance of Ascomycota was higher in the $2-4 \mathrm{~mm}$ and $<0.25 \mathrm{~mm}$ aggregates than in the $1-2 \mathrm{~mm}$ and $0.25-1 \mathrm{~mm}$ aggregates in the treatment without litter addition, and the relative abundance of Aphelidiomycota was lower in the 2-4 mm and $<0.25 \mathrm{~mm}$ aggregates than in the $1-2 \mathrm{~mm}$ and $0.25-1 \mathrm{~mm}$ aggregates. Soil $\mathrm{pH}$ and $\mathrm{SOC}$ were found to be the determining factors shaping the bacterial communities. The bacterial Shannon index had a significantly positive

Peer] reviewing PDF | (2019:06:38968:2:0:NEW 12 Oct 2019) 
241 and direct effect on SOC concentration and $\mathrm{CO}_{2}$ release, while the fungal Shannon index showed a significant

242 correlation with SOC concentration. Our results indicate that soil bacterial diversity contributes positively to

243 both carbon emissions and carbon storage, whereas soil fungal diversity can promote carbon storage and decrease

244 carbon emissions.

\section{Acknowledgments}

246 We are very grateful to the workers at the Hebei National Field Research Station of Grassland Science for their help during field work.

\section{References}

Bamminger C, Zaiser N, Zinsser P, Lamers M, Kammann C, and Marhan S. 2014. Effects of biochar, earthworms, and litter addition on soil microbial activity and abundance in a temperate agricultural soil. Biology And Fertility Of Soils 50:1189-1200.

\section{Begon M, Harper JL, and Townsend CR. 1986. Ecology: Individuals, populations and communities.}

Bonan GB, Hartman MD, Parton WJ, and Wieder WR. 2013. Evaluating litter decomposition in earth system models with longterm litterbag experiments: an example using the Community Land Model version 4 (CLM4). Global Change Biology 19:957-974. 10.1111/gcb.12031

Bradford MA, Berg B, Maynard DS, Wieder WR, and Wood SA. 2016. Understanding the dominant controls on litter decomposition. Journal Of Ecology 104:229-238. 10.1111/1365-2745.12507

Bronick CJ, and Lal R. 2005. Soil structure and management: a review. Geoderma 124:3-22. 10.1016/j.geoderma.2004.03.005

Chen WQ, Xu R, Wu YT, Chen J, Zhang YJ, Hu TM, Yuan XP, Zhou L, Tan TY, and Fan JR. 2018. Plant diversity is coupled with beta not alpha diversity of soil fungal communities following $\mathrm{N}$ enrichment in a semi-arid grassland. Soil Biology \& Biochemistry 116:388-398.

Effmert U, Kalderas J, Warnke R, and Piechulla B. 2012. Volatile Mediated Interactions Between Bacteria and Fungi in the Soil. Journal Of Chemical Ecology 38:665-703. 10.1007/s10886-012-0135-5

Fanin N, and Bertrand I. 2016. Aboveground litter quality is a better predictor than belowground microbial communities when estimating carbon mineralization along a land-use gradient. Soil Biology \& Biochemistry 94:48-60. 10.1016/j.soilbio.2015.11.007

Frey SD. 2005. Aggregation-microbial Aspects. In: Hillel, D. (Ed.), Encyclopedia of Soils in the Environment. Elsevier Ltd, USA:22-28.

Gupta VVSR, and Germida JJ. 2015. Soil aggregation: Influence on microbial biomass and implications for biological processes. 
Soil Biology \& Biochemistry 80:A3-A9. 10.1016/j.soilbio.2014.09.002

271

272

273

He XB, Lin YH, Han GM, Guo P, and Tian XJ. 2010. The effect of temperature on decomposition of leaf litter from two tropical forests by a microcosm experiment. European Journal Of Soil Biology 46:200-207. 10.1016/j.ejsobi.2010.02.001

Hishinuma T, Azuma JI, Osono T, and Takeda H. 2017. Litter quality control of decomposition of leaves, twigs, and sapwood by the white-rot fungus Trametes versicolor. European Journal Of Soil Biology 80:1-8. 10.1016/j.ejsobi.2017.03.002

Jia XQ, He ZH, Weiser MD, Yin T, Akbar S, Kong XS, Tian K, Jia YY, Lin H, Yu MJ, and Tian XJ. 2016. Indoor evidence for the contribution of soil microbes and corresponding environments to the decomposition of Pinus massoniana and Castanopsis sclerophylla litter from Thousand Island Lake. European Journal Of Soil Biology 77:44-52. 10.1016/j.ejsobi.2016.10.003

Keiser AD, and Bradford MA. 2017. Climate masks decomposer influence in a cross-site litter decomposition study. Soil Biology \& Biochemistry 107:180-187. 10.1016/j.soilbio.2016.12.022

Lane DJ, Pace B, Olsen GJ, Stahl DA, Sogin ML, and Pace NR. 1985. Rapid determination of 16S ribosomal RNA sequences for phylogenetic analyses. Proceedings Of the National Academy Of Sciences Of the United States Of America 82:69556959. 10.1073/pnas.82.20.6955

Lauber CL, Hamady M, Knight R, and Fierer N. 2009. Pyrosequencing-Based Assessment of Soil pH as a Predictor of Soil Bacterial Community Structure at the Continental Scale. Applied And Environmental Microbiology 75:5111-5120. 10.1128/Aem.00335-09

Liang X, Yuan J, Yang E, and Meng J. 2017. Responses of soil organic carbon decomposition and microbial community to the addition of plant residues with different C:N ratio. European Journal Of Soil Biology 82:50-55. 10.1016/j.ejsobi.2017.08.005

Lu WJ, Liu N, Zhang YJ, Zhou JQ, Guo YP, and Yang X. 2017. Impact of vegetation community on litter decomposition: Evidence from a reciprocal transplant study with C-13 labeled plant litter. Soil Biology \& Biochemistry 112:248-257. 10.1016/j.soilbio.2017.05.014

Meidute S, Demoling F, and Baath E. 2008. Antagonistic and synergistic effects of fungal and bacterial growth in soil after adding different carbon and nitrogen sources. Soil Biology \& Biochemistry 40:2334-2343. 10.1016/j.soilbio.2008.05.011

Neumann D, Heuer A, Hemkemeyer M, Martens R, and Tebbe CC. 2013. Response of microbial communities to long-term fertilization depends on their microhabitat. Fems Microbiology Ecology 86:71-84. 10.1111/1574-6941.12092

Phillips RL, Zak DR, Holmes WE, and White DC. 2002. Microbial community composition and function beneath temperate trees exposed to elevated atmospheric carbon dioxide and ozone. Oecologia 131:236-244. 10.1007/s00442-002-0868-x

Purahong W, Wubet T, Lentendu G, Schloter M, Pecyna MJ, Kapturska D, Hofrichter M, Kruger D, and Buscot F. 2016. Life in leaf litter: novel insights into community dynamics of bacteria and fungi during litter decomposition. Molecular Ecology 
Riggs CE, Hobbie SE, Cavender-Bares J, Savage JA, and Wei XJ. 2015. Contrasting effects of plant species traits and moisture on the decomposition of multiple litter fractions. Oecologia 179:573-584. 10.1007/s00442-015-3352-0

Rousk J, Baath E, Brookes PC, Lauber CL, Lozupone C, Caporaso JG, Knight R, and Fierer N. 2010. Soil bacterial and fungal communities across a pH gradient in an arable soil. Isme Journal 4:1340-1351. 10.1038/ismej.2010.58

Schimel JP, and Schaeffer SM. 2012. Microbial control over carbon cycling in soil. Frontiers In Microbiology 3 . Artn 348 DAC, Nannipieri P, Rasse DP, Weiner S, and Trumbore SE. 2011. Persistence of soil organic matter as an ecosystem property. Nature 478:49-56. 10.1038/nature10386

Schuman GE, Janzen HH, and Herrick JE. 2002. Soil carbon dynamics and potential carbon sequestration by rangelands. Environmental Pollution 116:391-396. Doi 10.1016/S0269-7491(01)00215-9

Six J, Bossuyt H, Degryze S, and Denef K. 2004. A history of research on the link between (micro)aggregates, soil biota, and soil organic matter dynamics. Soil \& Tillage Research 79:7-31. 10.1016/j.still.2004.03.008

Sun H, Wang QX, Liu N, Li L, Zhang CG, Liu ZB, and Zhang YY. 2017. Effects of different leaf litters on the physicochemical

Tlaskal V, Voriskova J, and Baldrian P. 2016. Bacterial succession on decomposing leaf litter exhibits a specific occurrence pattern

10.1093/femsec/fiw177

Wang QK, Zeng ZQ, and Zhong MC. 2016. Soil Moisture Alters the Response of Soil Organic Carbon Mineralization to Litter Addition. Ecosystems 19:450-460. 10.1007/s10021-015-9941-2

Wang SQ, Li TX, and Zheng ZC. 2017. Distribution of microbial biomass and activity within soil aggregates as affected by tea plantation age. Catena 153:1-8. 10.1016/j.catena.2017.01.029

White TJ, Bruns T, Lee S, and Taylor J. 1990. Amplification and direct sequencing of fungal ribosomal RNA genes for

Yang C, Liu N, and Zhang YJ. 2017. Effects of aggregates size and glucose addition on soil organic carbon mineralization and phylogenetics.

Wieder WR, Bonan GB, and Allison SD. 2013. Global soil carbon projections are improved by modelling microbial processes. Nature Climate Change 3:909-912. 10.1038/Nclimate1951 Q(10) values under wide temperature change conditions. European Journal Of Soil Biology 80:77-84. 10.1016/j.ejsobi.2017.04.002 
332 Yang C, Liu N, and Zhang YJ. 2019a. Soil aggregates regulate the impact of soil bacterial and fungal communities on soil respiration. Geoderma 337:444-452.

334 Yang C, Liu N, and Zhang YJ. 2019b. Soil aggregates regulate the impact of soil bacterial and fungal communities, on soil respiration. Geoderma 337:444-452. 10.1016/j.geoderma.2018.10.002

Yang C, Zhang YJ, Rong YP, Bei YX, Wei YQ, and Liu N. 2018. Temporal variation of Q(10) values in response to changes in soil physiochemical properties caused by fairy rings. European Journal Of Soil Biology 86:42-48.

Zhang WD, Chao L, Yang QP, Wang QK, Fang YT, and Wang SL. 2016. Litter quality mediated nitrogen effect on plant litter decomposition regardless of soil fauna presence. Ecology 97:2834-2843. 10.1002/ecy.1515

Zhong YQW, Yan WM, Wang RW, and Shangguan ZP. 2017. Differential responses of litter decomposition to nutrient addition and soil water availability with long-term vegetation recovery. Biology And Fertility Of Soils 53:939-949. 


\section{Table $\mathbf{1}$ (on next page)}

Table 1

Mean [ \pm standard error (SE), $n=3$ ] total carbon $(\mathrm{TC})$, total nitrogen $(\mathrm{TN})$, and carbon to nitrogen ration $(\mathrm{C} / \mathrm{N})$ for different soil aggregate size classes and litter types. 
1

\begin{tabular}{|c|c|c|c|c|c|c|c|}
\hline & \multicolumn{4}{|c|}{ Soil aggregates } & & \multicolumn{2}{|c|}{ Litter type } \\
\hline & $2-4 \mathrm{~mm}$ & $1-2 \mathrm{~mm}$ & $0.25-1 \mathrm{~mm}$ & $<0.25 \mathrm{~mm}$ & & Leaf & Stem \\
\hline $\operatorname{SOC}\left(\mathrm{g} \mathrm{kg}^{-1}\right)$ & $13.27(0.1) \mathrm{ab}$ & $11.87(0.2) \mathrm{b}$ & $5.20(0.2) \mathrm{c}$ & $14.17(0.3) \mathrm{a}$ & $\mathrm{TC}\left(\mathrm{g} \mathrm{kg}^{-1}\right)$ & $411.96(0.1) \mathrm{c}$ & $424.19(0.1) \mathrm{a}$ \\
\hline $\mathrm{TN}\left(\mathrm{g} \mathrm{kg}^{-1}\right)$ & $1.67(0.03) b c$ & $1.73(0.03) \mathrm{b}$ & $1.07(0.07) \mathrm{c}$ & $1.90(0.06) \mathrm{a}$ & $\mathrm{TN}\left(\mathrm{g} \mathrm{kg}^{-1}\right)$ & $17.20(0.1) \mathrm{a}$ & $14.30(0.1) \mathrm{c}$ \\
\hline $\mathrm{C} / \mathrm{N}$ ratios & $7.95(0.01) \mathrm{a}$ & $6.86(0.01) \mathrm{b}$ & $4.86(0.02) \mathrm{c}$ & $7.46(0.01) \mathrm{a}$ & $\mathrm{C} / \mathrm{N}$ ratios & $23.95(0.1) \mathrm{c}$ & $29.66(0.1) \mathrm{a}$ \\
\hline
\end{tabular}

2 Different letters in the same row indicate a significant difference at $P<0.05$ using least significant difference tests. 


\section{Table 2 (on next page)}

Table 2

Diversity of the bacterial and fungal communities and soil properties in each aggregate under litter addition conditions. 
1

\begin{tabular}{|c|c|c|c|c|c|c|c|c|}
\hline \multirow{2}{*}{$\begin{array}{l}\text { Litter } \\
\text { addition }\end{array}$} & \multirow{2}{*}{ Sizes } & \multirow{2}{*}{$\begin{array}{l}\text { Bacterial } \\
\text { Shannon }\end{array}$} & \multirow{2}{*}{$\begin{array}{l}\text { Fungal } \\
\text { Shannon }\end{array}$} & \multirow{2}{*}{$\begin{array}{l}\text { Soil organic } \\
\text { carbon }\left(\mathrm{g} \mathrm{kg}^{-1}\right)\end{array}$} & \multirow{2}{*}{$\begin{array}{l}\mathrm{CO}_{2} \text { release (mg } \\
\left.\mathrm{C} \mathrm{kg}^{-1} \text { day }^{-1}\right)\end{array}$} & \multirow{2}{*}{ Soil pH } & \multicolumn{2}{|c|}{ Litter mass loss (\%) } \\
\hline & & & & & & & Day 28 & Day 56 \\
\hline \multirow[t]{4}{*}{ CK } & $2-4 \mathrm{~mm}$ & $6.75(0.10)$ & $4.06(0.16)$ & $13.19(0.05)$ & $61.78(4.9)$ & 7.93(0.01) & & \\
\hline & $1-2 \mathrm{~mm}$ & $6.96(0.03)$ & $3.19(0.07)$ & $11.39(0.10)$ & 89.47(3.5) & $8.02(0.01)$ & & \\
\hline & $0.25-1 \mathrm{~mm}$ & $6.83(0.04)$ & $3.52(0.30)$ & $5.12(0.01)$ & $23.28(3.5)$ & $8.25(0.01)$ & & \\
\hline & $<0.25 \mathrm{~mm}$ & $6.87(0.04)$ & $4.01(0.04)$ & $14.10(0.04)$ & $43.28(3.5)$ & $8.02(0.01)$ & & \\
\hline \multirow[t]{4}{*}{ Leaf } & $2-4 \mathrm{~mm}$ & $6.77(0.03)$ & $2.43(0.04)$ & $14.65(0.10)$ & $213.95(3.8)$ & $7.77(0.01)$ & $29.3(3.2)$ & $39.4(2.0)$ \\
\hline & $1-2 \mathrm{~mm}$ & $6.87(0.06)$ & $2.47(0.05)$ & $14.66(0.10)$ & $281.60(0.8)$ & $7.82(0.01)$ & $32.4(1.0)$ & $43.3(1.5)$ \\
\hline & $0.25-1 \mathrm{~mm}$ & $6.72(0.02)$ & $2.51(0.08)$ & $8.60(0.10)$ & $148.68(1.4)$ & $7.87(0.01)$ & $25.9(2.0)$ & $33.9(2.1)$ \\
\hline & $<0.25 \mathrm{~mm}$ & $6.73(0.03)$ & $2.45(0.08)$ & $16.87(0.20)$ & $178.68(1.4)$ & $7.73(0.01)$ & $16.9(2.1)$ & $21.9(2.0)$ \\
\hline \multirow[t]{4}{*}{ Stem } & $2-4 \mathrm{~mm}$ & $6.81(0.04)$ & $2.77(0.02)$ & $14.29(0.12)$ & $160.42(4.9)$ & $7.87(0.01)$ & $26.3(3.0)$ & $36.3(1.5)$ \\
\hline & $1-2 \mathrm{~mm}$ & $6.82(0.03)$ & $2.90(0.1)$ & $13.61(0.10)$ & 207.17(5.1) & $7.91(0.01)$ & $29.8(2.0)$ & 40.8(3.0) \\
\hline & $0.25-1 \mathrm{~mm}$ & $6.65(0.05)$ & $2.80(0.04)$ & $9.00(0.50)$ & $24.75(7.3)$ & 8.03(0.02) & $22.1(2.1)$ & $30.1(3.0)$ \\
\hline & $<0.25 \mathrm{~mm}$ & $6.85(0.01)$ & $2.47(0.15)$ & $16.66(0.04)$ & $49.75(7.3)$ & $7.85(0.01)$ & $10.9(3.0)$ & $15.9(2.0)$ \\
\hline \multicolumn{9}{|c|}{ Two-way ANOVA } \\
\hline Litter & & $*$ & $* * *$ & $* * *$ & $* * *$ & $* * *$ & $* *$ & $* *$ \\
\hline Sizes & & $* *$ & $* *$ & $* * *$ & $* * *$ & $* * *$ & $* * *$ & $* * *$ \\
\hline \multicolumn{2}{|c|}{ Litter $\times$ Sizes } & ns & $* * *$ & $* * *$ & $* * *$ & $* * *$ & $* * *$ & $* * *$ \\
\hline
\end{tabular}

2 Values are means ( \pm SE) of three measurements. The highest value among the four aggregate sizes are in bold. Level

3 of significance: $* P<0.05,{ }^{* *} P<0.01,{ }^{* * *} P<0.001$, ns: not significant. 
Figure 1

Fig. 1.

Nonmetric multidimensional scaling (NMDS) ordinations based on the mean abundance value of the bacterial phyla under no litter addition (A), leaf addition (B), and stem addition (C), and the fungal phyla under no litter addition (D), leaf addition (E), and stem addition (F).

Communities are indicated by colored symbols as follows: red circles, 2-4 mm; blue triangles, 1-2 mm; green plus signs, 0.25-1 mm, and purple times signs, $<0.25 \mathrm{~mm}$.
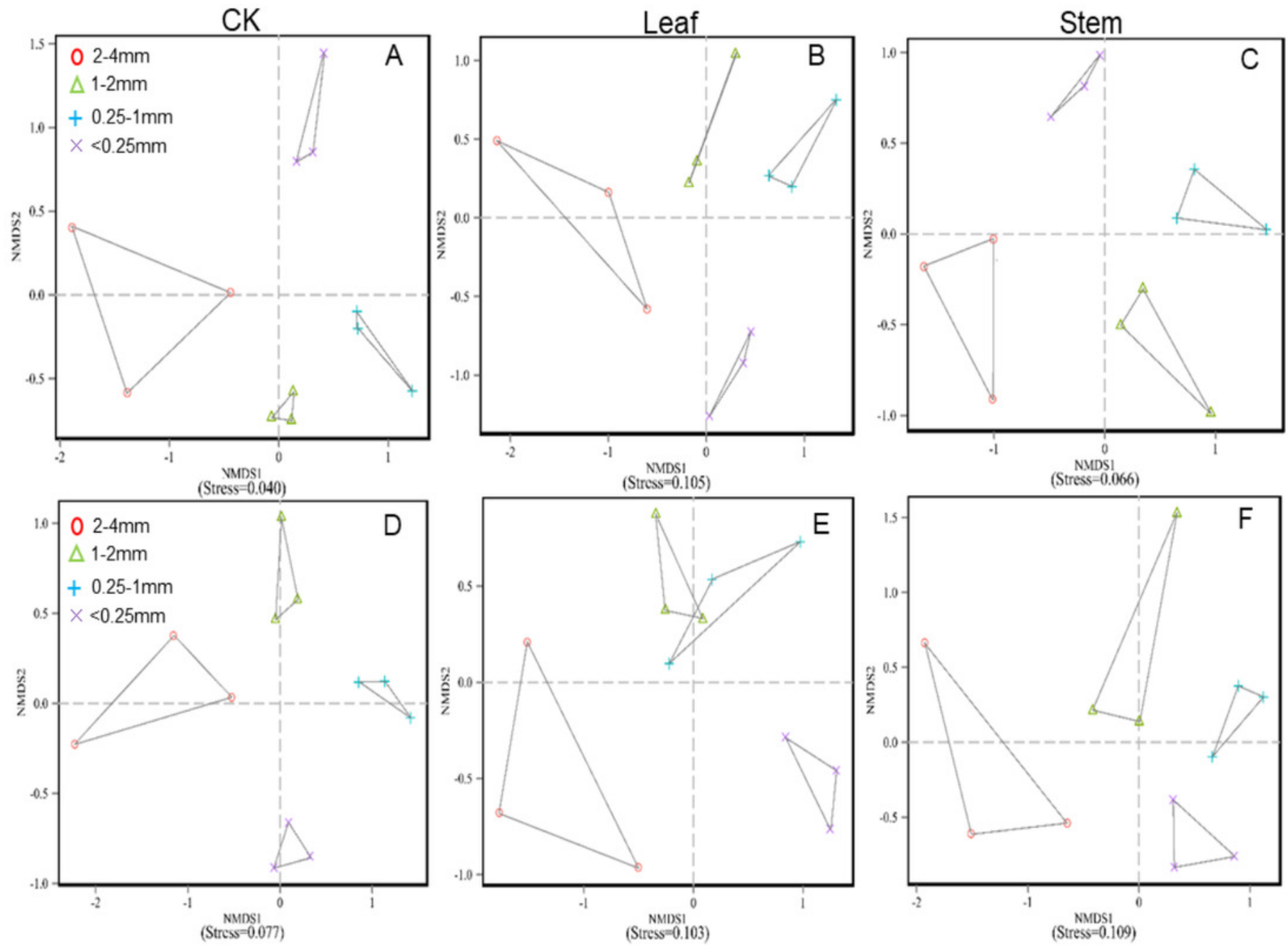


\section{Figure 2}

Fig. 2.

Fig. 2. The relative abundances of the bacterial (A-C) and fungal phyla (D-F) in different sized aggregates. The abundances that accounted for $<1 \%$ of all of the classified sequences belong to Others in the bar graph.

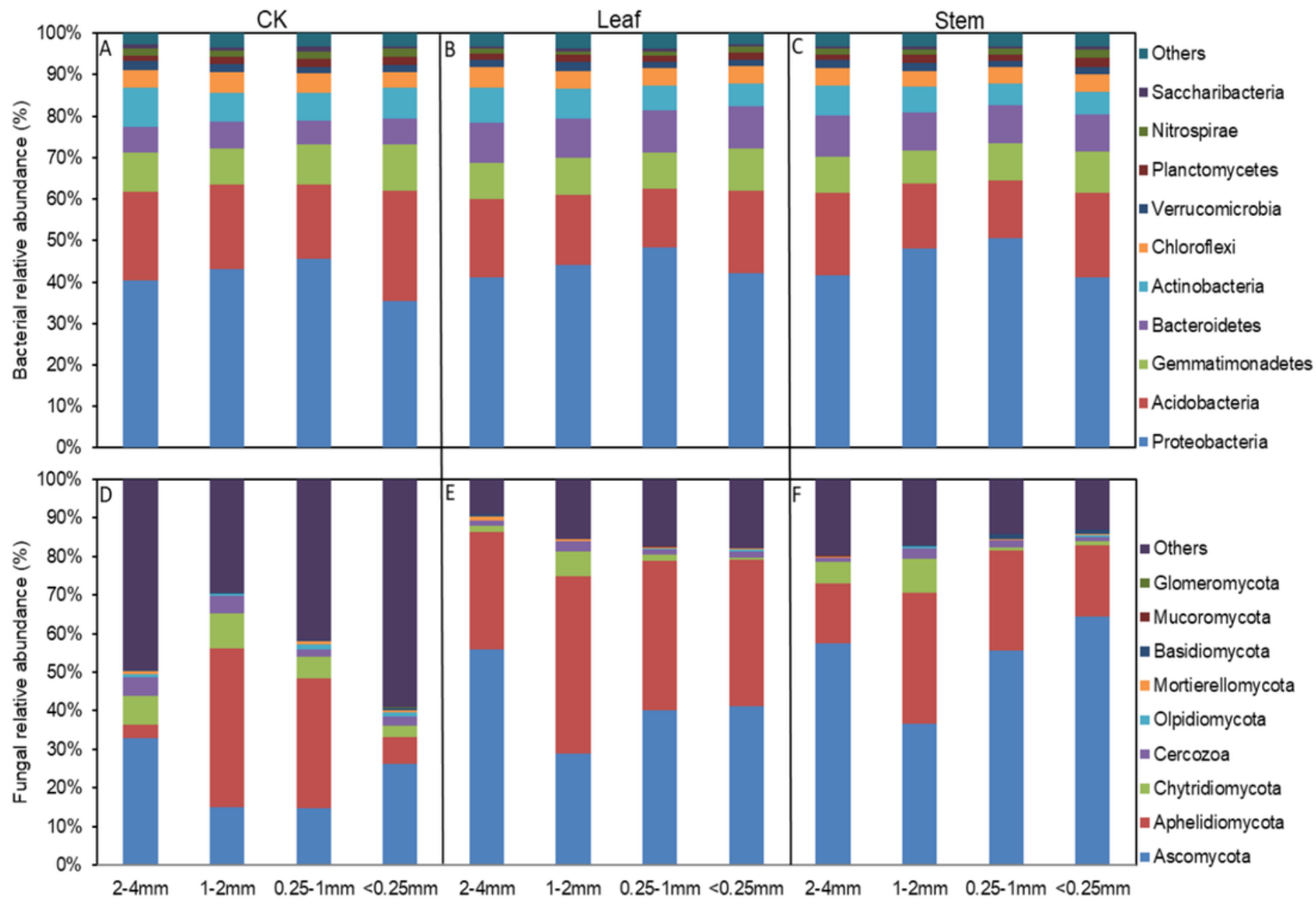


Figure 3

Fig. 3.

The changed abundances of the dominant bacterial $(A, B)$ and fungal phyla $(C, D)$ in differentsized aggregates under litter addition compared with no litter addition. The abundances that accounted for $<1 \%$ of all of the classified sequences belong to Others in the bar graph.

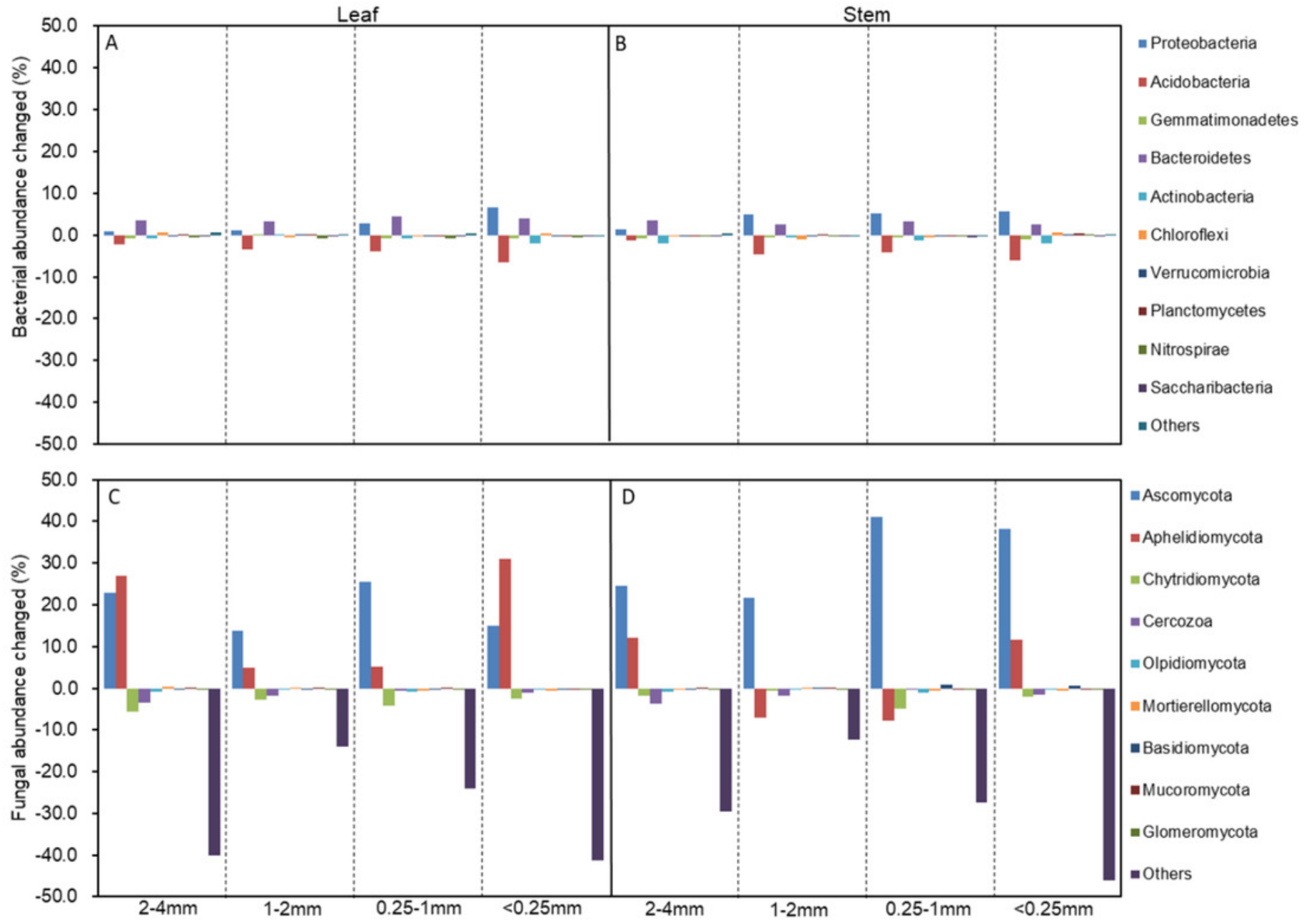




\section{Figure 4}

Fig. 4.

Fig. 4. The redundancy analysis (RDA) showing the impact of soil properties ( $\mathrm{SOC}$ and $\mathrm{pH}$ ) on bacterial (A) and fungal (B) community structures. the significance of the effect of each variable, based on its eigenvalue, was tested using the Monte Carlo Permutation test, and the resulting significance level was determined by the $\mathrm{F}$ ratio and P-value. Communities are indicated by symbols as follows: circles, no litter addition; squares, leaf addition; diamonds, stem addition.
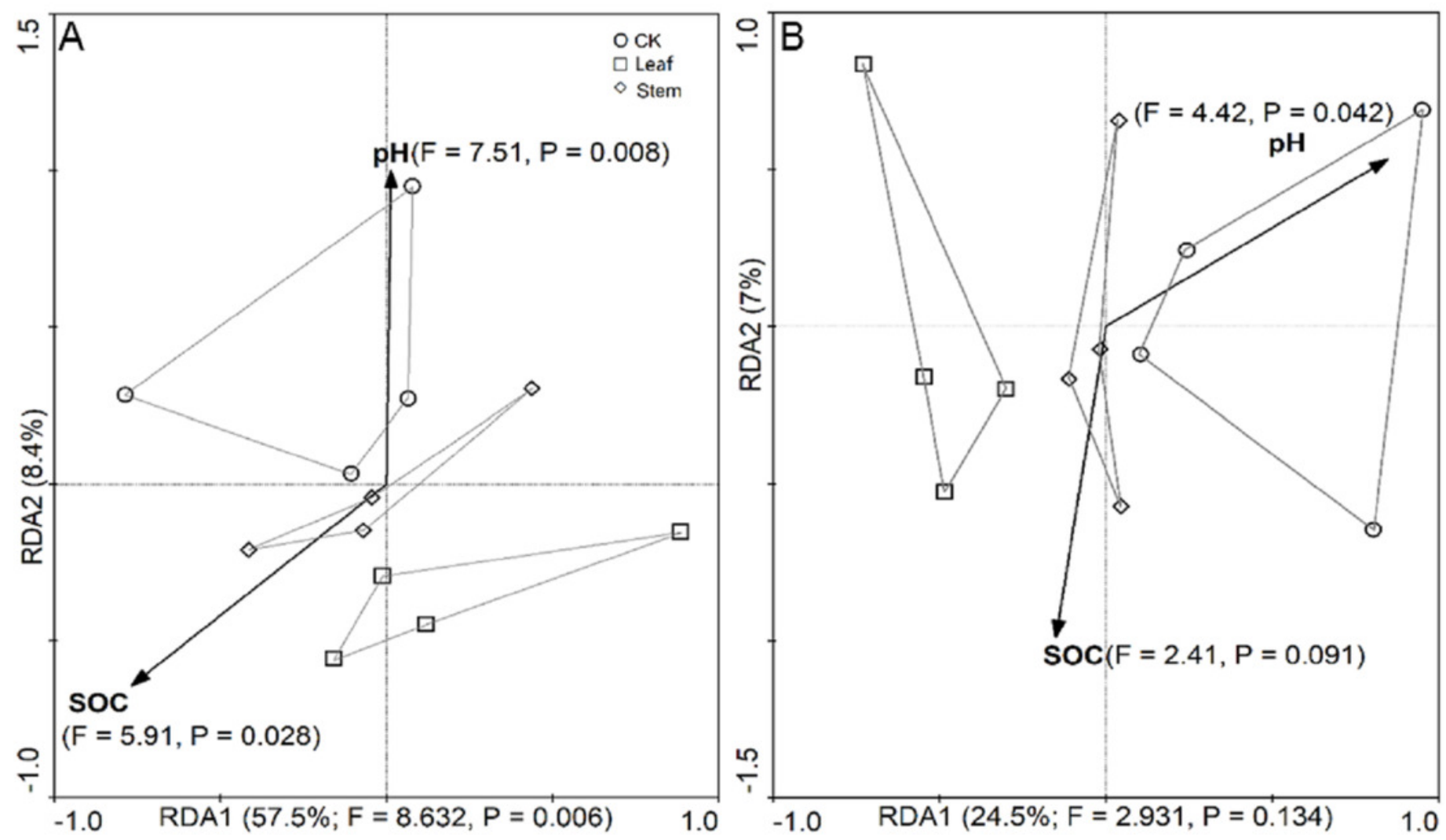


\section{Figure 5}

Fig. 5.

Fig. 5. Structural equation model (SEM) based on the effects of the bacterial and fungal Shannon index on soil pH, SOC, and respiration under litter addition conditions (A), and their standardized total effects (direct plus indirect effects) derived from the structural equation models of SOC and $\mathrm{CO} 2$ release (B). Continuous and dashed arrows indicate positive and negative relationships, respectively. The width of the arrows is proportional to the strength of the path coefficients. R2 indicates the proportion of the variance explained and appears above every response variable in the model.
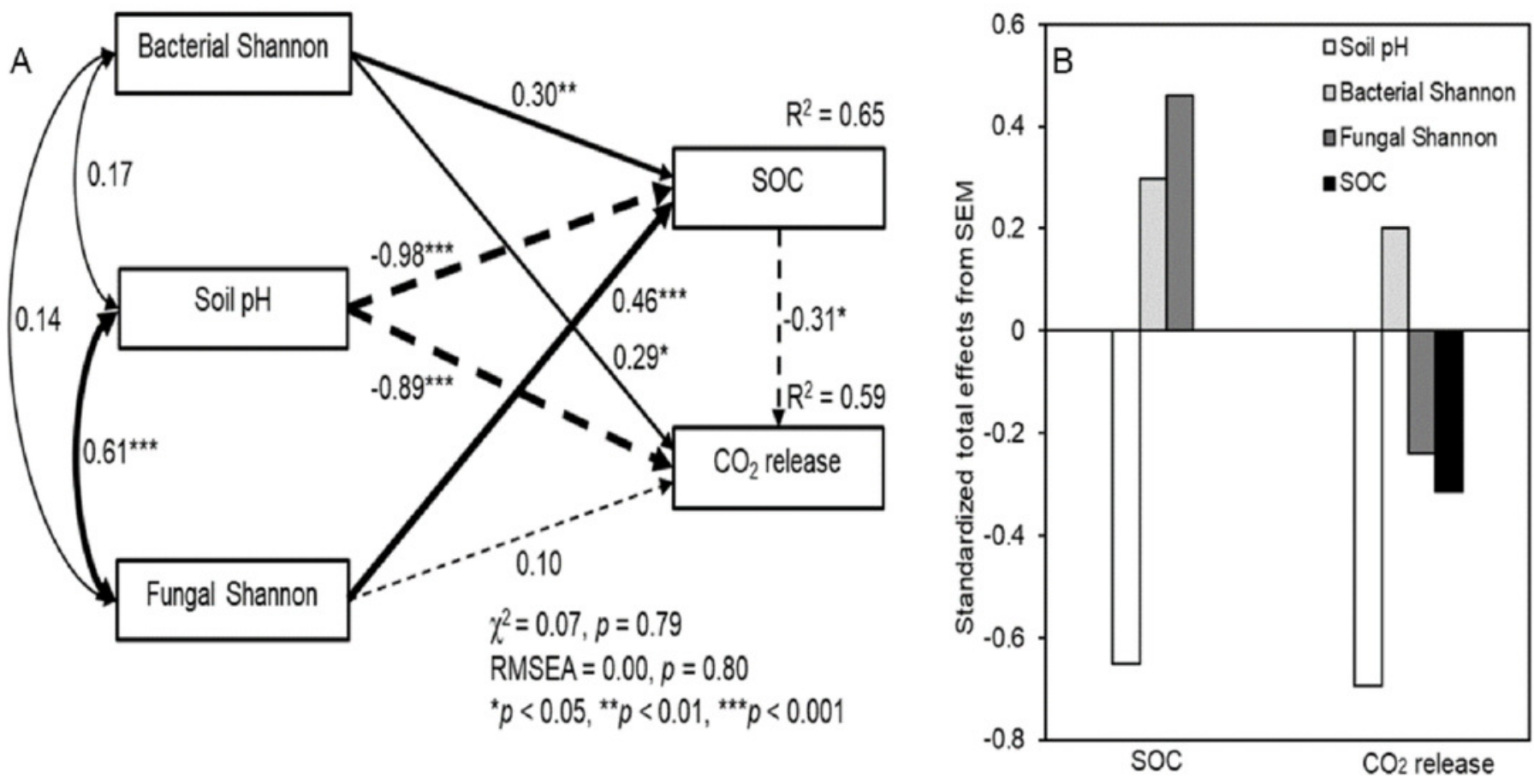